\title{
Preliminary Comparative Analysis of Phenological Varieties of Quercus robur by ISSR-Markers
}

\author{
Vasiliy Chokheli, ${ }^{1}$ Boris Kozlovsky, ${ }^{1}$ Mikhail Sereda, ${ }^{1}$ Vladimir Lysenko, ${ }^{1}$ Igor Fesenko, ${ }^{2}$ \\ Tatiana Varduny, ${ }^{1}$ Olga Kapralova, ${ }^{1}$ and Elena Bondarenko ${ }^{1}$ \\ ${ }^{1}$ Academy of Biology and Biotechnology, Southern Federal University, Rostov-on-Don 344 041, Russia \\ ${ }^{2}$ Shemyakin-Ovchinnikov Institute of Bioorganic Chemistry, Russian Academy of Sciences, Moscow 117 997, Russia \\ Correspondence should be addressed to Vasiliy Chokheli; vachokheli@sfedu.ru
}

Received 29 October 2015; Revised 16 January 2016; Accepted 21 January 2016

Academic Editor: Lorenzo Peruzzi

Copyright (C) 2016 Vasiliy Chokheli et al. This is an open access article distributed under the Creative Commons Attribution License, which permits unrestricted use, distribution, and reproduction in any medium, provided the original work is properly cited.

Quercus robur $\mathrm{L}$. is a valuable wood species having long ontogeny and promising to create long-living artificial plantings of recreational and ameliorative purposes in the steppes zone of Russia and other countries. In this work we have performed the genotyping of varieties of Quercus robur L. obtained from collection of Botanical Garden of Southern Federal University using intersimple sequence repeat (ISSR) molecular markers. The most polymorphic ISSR-marker (GA) 8YC was found in the collection. The polymorphic DNA markers identified in the present study can be used for the future breeding works to obtain valuable genotypes of Quercus genus. In addition we have performed DNA fingerprinting of the prospective sample of the variety $Q$. robur var. tardiflora Czern.

\section{Introduction}

Efficient creation of artificial forests should be based on the use of a genetically diversified planting material of high-quality. Among such a material the English oak (Quercus robur L.) is an important component of artificial forest plantations [1].

Q. robur is a widespread species in the natural forest associations [2] of the middle latitudes and mountainous zones of the northern hemisphere and Asia Minor (an area corresponding to the western two-thirds of Turkey), North Africa, the Caucasus, and Europe [3]. The actual area occupied by Q. robur in Russia is located within the subzone of broad-leaved forests and forest-steppe of the European part of the country [4].

Now $Q$. robur cannot be found in the natural associations of West Siberia flora, although oak forests are an essential part of the forest-steppe zone of Western Siberia.

Wide distribution of $Q$. robur in the area of the continental climate is characterized by its freeze-thaw resistance $[5,6]$. Q. robur refers to salt-tolerant woody plants growing satisfactorily in saline soils [7]. However, some authors have an opposite view $[8,9]$. There are different, conflicting data related to $Q$. robur. Pogrebnyak showed that $Q$. robur is a xeromesophyte [10]. Accordingly to other data Q. robur is very tolerant to soil conditions and the continental climate but it prefers fertile and well-watered soils $[7,11]$. However, it is capable of growing in conditions of high humidity [12]. Drought resistance of $Q$. robur is primarily determined by its strong root system, so this species can grow on dry poor, rocky soils.

Currently, this type of Q. robur habitat becomes mobile and reduced in size due to its substitution by other species [3].

Significant reduction in the duration of the ontogeny is a serious problem of artificial plantations of $Q$. robur $[13,14]$.

In this connection the following varieties of $Q$. robur $\mathrm{L}$. (firstly described by Chernyaev [15] in 1858) are of interest: $Q$. robur var. praecox Czern. and Q. robur var. tardiflora Czern., which differ in time of occurrence of their phenological phases.

Two varieties of Quercus robur were studied: $Q$. robur var. tardifolia and Q. robur var. praecox, which are cultivated in the Botanical Garden of Southern Federal University. 
The main diagnostic signs to distinguish Quercus robur var. tardiflora Czern. and Quercus robur var. praecox Czern. are [16] as follows:

(1) Bud, bloom, beginning of shoot growth, and most other phenological phases occur in Quercus robur var. tardiflora Czern. at 2-3 weeks later than in Quercus robur var. praecox Czern.

(2) In contrast to Quercus robur var. praecox Czern, the senescent leaves of Quercus robur var. tardiflora Czern. do not fall down, remaining on the shoots until the end of winter.

(3) Q. robur var. tardiflora is less defeated by pests and diseases.

(4) Comparing to Quercus robur var. praecox Czern, Q. robur var. tardiflora has a higher and a more regular crown shape, straighter trunk, and a higher quality of wood. It prefers moist habitats.

Q. robur var. praecox, which was referred to in an experiment as a typical form, may be found all over the artificial population of Q. robur in the Botanical Garden.

Only two samples have been selected and described from the population in conformity with the phenological cycle of Q. robur var. tardiflora. The first (N 1) was planted in 1888 and the second (N 2) in 1975.

The first sample of $Q$. robur var. tardiflora is the most interesting. Q. robur var. tardiflora Czern. (N 1) has a high decorative quality and exceeds other samples in duration of ontogenesis.

In contrast to the specimens of Q. robur var. praecox, planted in similar conditions in the Botanical Garden in 1930, it has no signs of ageing.

It differs from $Q$. robur var. tardiflora in that it sheds leaves at the time characteristic for deciduous species that significantly enhances its decorative properties.

This sample currently has a height of 26 meters and trunk diameter of 108 centimeters.

The phenological characteristics of $Q$. robur var. tardiflora Czern. and Q. robur var. praecox Czern were showed in Tables 1 and 2.

The annual time scale of phenological cycle is shown in Table 2.

Samples of $Q$. robur var. praecox were selected from three different generations of specimens (see Table 2): N 1 and N 2 planted in 1930, N 3 in 1963, and N 4 and N 5 in 1975.

Several authors have noted that these varieties have significant differences in the environmental stress resistance, growth, and development [17-23].

Q. robur var. tardiflora is a promising and prospective variety, which, however, is already widely used for the artificial formation of green areas in European countries [24]. From such a point of view, this variety has been shown as the most promising that was the result of studies conducted during last few years at the Botanical Garden of the Southern Federal University [13].

Obviously, a clear genetic identification Q. robur var. tardiflora will allow identifying its other, closely allied varieties, as well as identifying the individual, most genetically
TABLE 1: Time scale of phenological phases of Q. robur varieties.

\begin{tabular}{lcc}
\hline \multirow{2}{*}{ Phenological phases } & \multicolumn{2}{c}{ Calendar date } \\
& Q. $r$. var. praecox & Q. $r$. var. tardiflora \\
\hline Bud & $14 . \mathrm{IV} \pm 2.1$ & $21 . \mathrm{IV} \pm 3.4$ \\
Beginning of shoot growth & $15 . \mathrm{IV} \pm 2.3$ & $24 . \mathrm{IV} \pm 2.7$ \\
Leafing & $18 . \mathrm{IV} \pm 2.1$ & $1 . \mathrm{V} \pm 2.2$ \\
Efflorescence & $24 . \mathrm{IV} \pm 2.7$ & $5 . \mathrm{V} \pm 2.7$ \\
Full leafy & $28 . \mathrm{IV} \pm 2.1$ & $9 . \mathrm{V} \pm 2.1$ \\
End of flowering & $2 . \mathrm{V} \pm 2.7$ & $7 . \mathrm{V} \pm 2.2$ \\
End of shoot growth & $20 . \mathrm{V} \pm 4.5$ & $29 . \mathrm{V} \pm 8.2$ \\
Secondary shoot growth & $15 . \mathrm{VI} \pm 8.2$ & $30 . \mathrm{VI} \pm 14.6$ \\
Full maturation of shoots & $24 . \mathrm{VII} \pm 6.5$ & $7 . \mathrm{VIII} \pm 8.2$ \\
Mass staining & $5 . \mathrm{X} \pm 3.4$ & $13 . \mathrm{X} \pm 8.5$ \\
Massive maturation of seeds & $4 . \mathrm{IX} \pm 5.7$ & $16 . \mathrm{IX} \pm 2.6$ \\
Massive fruit abscission & $13 . \mathrm{IX} \pm 8.9$ & $21 . \mathrm{IX} \pm 6.4$ \\
Massive defoliation & $12 . \mathrm{X} \pm 1.3$ & $28 . \mathrm{X} \pm 4.1$ \\
\hline
\end{tabular}

valuable specimens for the further propagation via in vitro culture and the subsequent bulk producing of planting material.

A number of works provide the detailed information on the application of ISSR- and SSR-markers for the study of genetic divergence in the cortical oaks $[25,26]$ and assessment of phylogenetic relationships [27], as well as on the use of intermicrosatellite DNA markers for genotyping of the family Fagaceae [2, 24, 27-29].

The aim of this work is to study the genetic affinity of $Q$. robur var. tardiflora Czern. and Q. robur var. praecox Czern. using ISSR-markers, as well as the applicability of different ISSR-markers for genetic analysis of kinship relationships within the genus Quercus.

\section{Materials and Methods}

2.1. Plant Material. Samples of Q. robur var. praecox were selected from three different generations of specimens (see Table 2): N 1 and N 2 planted in 1930; N 3 in 1963; and N 4 and N 5 in 1975. Samples of Q. robur var. tardiflora were selected from three different generations of specimens. $\mathrm{N} 1$ was planted in 1888 and N 2 in 1975.

In addition, in order to predetermine the position of the selected varieties of $Q$. robur in the phylogenetic tree of the genus, the following samples were added: one sample of $Q$. robur var. "fastigiata" obtained by seeds and two samples of $Q$. petraea (Matt.) Liebl. (Russia, the Republic of Adygea) which is a species phylogenetically closest to Q. robur. Furthermore, one sample of Q. libani Oliv., Q. macrocarpa Michx, and Q. rubra L., respectively, was taken in the experiment as phylogenetically distant forms (Table 3).

2.2. DNA Extraction. Plant samples were obtained in a period from October 2014 to January 2015. Extraction DNA was performed from dormant oak buds freed from bud scales using a Sorb-A-GMO reagent kit (Sintol, Russia).

The intersimple sequence repeat- (ISSR-) method was performed for the analysis of the isolated DNA using six 
TABLE 2: Phenological cycle of Q. robur varieties in 2014.

\begin{tabular}{lccc}
\hline Phenological phases & & Calendar date & \\
& Q. $r$. var. praecox N 1 & Q. r. var. tardiflora N 1 & Q. $r$. var. tardiflora N 2 \\
\hline Bud & $10 . \mathrm{IV}$ & $24 . \mathrm{IV}$ & $21 . \mathrm{IV}$ \\
Beginning of shoot growth & $14 . \mathrm{IV}$ & $26 . \mathrm{IV}$ & $25 . \mathrm{IV}$ \\
Leafing & $14 . \mathrm{IV}$ & $26 . \mathrm{IV}$ & $25 . \mathrm{IV}$ \\
Efflorescence & $20 . \mathrm{IV}$ & $26 . \mathrm{IV}$ & $25 . \mathrm{IV}$ \\
Full leafy & $7 . \mathrm{V}$ & $12 . \mathrm{V}$ & $12 . \mathrm{V}$ \\
End of flowering & $30 . \mathrm{IV}$ & $3 . \mathrm{V}$ & $2 . \mathrm{V}$ \\
End of shoot growth & $15 . \mathrm{V}$ & $18 . \mathrm{V}$ & $18 . \mathrm{V}$ \\
Secondary shoot growth & $26 . \mathrm{V}$ & - & $28 . \mathrm{V}$ \\
Full shoot maturation & $10 . \mathrm{VII}$ & - & $10 . \mathrm{VII}$ \\
Mass staining & $15 . \mathrm{X}$ & $15 . \mathrm{X}$ & $15 . \mathrm{X}$ \\
Massive maturation of seeds & $4 . \mathrm{IX}$ & $7 . \mathrm{IX}$ & $10 . \mathrm{IX}$ \\
Massive fruit abscission & $10 . \mathrm{IX}$ & $14 . \mathrm{IX}$ & $14 . \mathrm{IX}$ \\
Massive defoliation & $27 . \mathrm{X}$ & $30 . \mathrm{X}$ & Do not fall down \\
\hline
\end{tabular}

TABLE 3: The total number of samples of Quercus L.

\begin{tabular}{lcc}
\hline Species & Variety & $\begin{array}{c}\text { Number of } \\
\text { samples }\end{array}$ \\
\hline Quercus robur & Quercus robur var. praecox & 5 \\
Quercus robur & Quercus robur var. tardiflora & 2 \\
Quercus robur & Q. robur var. "fastigiata” & 1 \\
Quercus libani & - & 1 \\
Quercus macrocarpa & - & 1 \\
Quercus rubra & - & 1 \\
Quercus petraea & - & 1 \\
\hline
\end{tabular}

TABLE 4: ISSR primer sequences.

\begin{tabular}{lcc}
\hline Primer name & Primer sequence & Annealing temperature $\left({ }^{\circ} \mathrm{C}\right)$ \\
\hline UBC 811 & $(\mathrm{GA})_{8} \mathrm{C}$ & 53 \\
UBC 835 & $(\mathrm{AG})_{8} \mathrm{YC}$ & 52 \\
UBC 841 & $(\mathrm{GA})_{8} \mathrm{YC}$ & 52 \\
UBC 857 & $(\mathrm{AC})_{8} \mathrm{YG}$ & 52 \\
UBC 878 & $(\mathrm{GGAT})_{4}$ & 53 \\
UBC 880 & $(\mathrm{GGAG})_{4}$ & 53 \\
\hline
\end{tabular}

$\mathrm{Y}$ is any pyrimidine.

oligonucleotide primers (two lines of three primers) with different annealing temperatures (Table 4) from "100/9 University British Columbia (UBC)" kit (University of Colombia, USA) $[25,27]$.

2.3. ISSR Amplification and Electrophoresis. The PCR mix was prepared calculating the following quantities of reagents per sample: $\mathrm{H}_{2} \mathrm{O}$ (DD), $15.8 \mu \mathrm{L}$; 10xdNTP, $2.5 \mu \mathrm{L}(25 \mathrm{mM})$; 10x PCR buffer, $2.5 \mu \mathrm{L}$; Mg, $2.5 \mu \mathrm{L}(25 \mathrm{mM})$; mutant Taqpolymerase, $0.2 \mu \mathrm{L}$ ( 5 unit $/ \mu \mathrm{L}$ ); DNA sample, $1 \mu \mathrm{L}$ and $0.5 \mu \mathrm{L}$ of primer $(10 \mathrm{OU} / \mu \mathrm{L})$. The total volume of the mixture was $25 \mu \mathrm{L}$.
Amplification was performed with a Thermal Cycler T100 (BioRad). Amplification protocol is as follows: $1,94^{\circ} \mathrm{C}$, $1.00 \mathrm{~min} ; 2,94^{\circ} \mathrm{C}, 0.30 \mathrm{~s} ; 3,52^{\circ} \mathrm{C} / 53^{\circ} \mathrm{C}, 0.45 \mathrm{~s} ; 4,72^{\circ} \mathrm{C}$, $2.00 \mathrm{~min} ; 5,35$ cycles from the second point; $6,72^{\circ} \mathrm{C}$, $5.00 \mathrm{~min} ; 7$, storage at $12^{\circ} \mathrm{C}$.

Separation of DNA fragments was performed by electrophoresis on a $2 \%$ agarose gel using TBE-buffer (Tris, boric acid, EDTA), at voltage of $100 \mathrm{~V}$ and duration 1.5 hours. DNA was stained with SYBR Green I.

DNA staining dye produced SYBR Green I of ratio $1 \mu \mathrm{L}$ of dye $5 \mu \mathrm{L}$ of DNA. Shoot made in GelDoc XR+ system (BioRad) software version 4.1 ImageLab.

Length marker of 100-1500 bp DNA fragments was added to $7 \mu \mathrm{L}$ per well.

2.4. Statistical Analysis. Computer processing of the derived electropherograms was performed using the program PyElph 1.4, followed by its presentation in the form of a matrix of binary data. Being dominant markers, the ISSRs were scored as presence (1) or absence (0) in order to construct binary matrices for statistical analysis. Only reproducible fragments (in repeated experiments) were considered, whereas the variation in intensity was ignored. Computer analysis of matrices was conducted using MS Excel. Hierarchical cluster analysis of the data was performed by Neighbor-Joining (NJ) and Unweighted Pair Group Average (UPGMA) methods [30], using programs TREECON (version 1.3b) and PyElph $1.4[31]$.

\section{Results and Discussion}

In our work, we used six ISSR primers to test genetic affinity of phenological forms $Q$. robur. The obtained data showed that marker UBC 878 has a lower specificity as compared with all varieties of $Q$. robur.

There was a slight amplification of PCR product in this case that, however, did not affect the analysis of the obtained amplicon spectra (Figure 1). 
TABLE 5: Analysis of information content of the primers.

\begin{tabular}{lccccc}
\hline & & \multicolumn{3}{c}{ Name of primers } \\
& UBC 811 & UBC 835 & UBC 841 & UBC 857 & 8 \\
Maximum number of amplicons & 10 & 12 & 11 & 11 \\
Minimum number of amplicons & 6 & 3 & 3 & 5 & 5 \\
Monomorphic fragments (unique), total number & 7 & 8 & 9 & 10 & 54.0 \\
Average percentage of polymorphism of ISSR & 93.6 & 88.8 & 85.9 & 91.6 \\
\hline
\end{tabular}

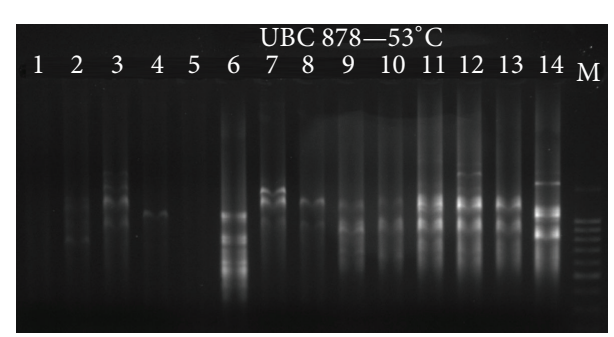

FIGURE 1: PCR detection of oak trees using the primer UBC 878. 1, Q. r. var. praecox $1 ; 2$, Q. $r$. var. praecox $2 ; 3$, Q. r. var. praecox 3; 4, Q. r. var. praecox 4; 5, Q. r. var. praecox 5; 6, Q. r. var. tardiflora 1; 7, Q. $r$. var. tardiflora 2; 8, Q. r. f. fastigiata; 9, Q. macrocarpa; 10, Q. libani; 11 , Q. rubra; 12, Q. petraea 1; 13, Q. petraea 2; 14, Q. petraea 3; M, the number of the base pair.

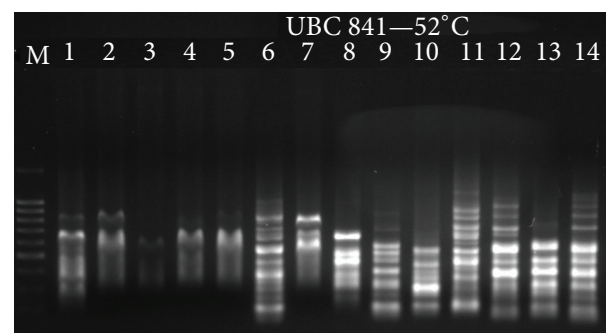

FIGURE 2: PCR detection of oak trees using the primer UBC 841. 1, Q. r. var. praecox 1; 2, Q. r. var. praecox 2; 3, Q. r. var. praecox 3; 4, Q. r. var. praecox 4; 5, Q. r. var. praecox 5; 6, Q. $r$. var. tardiflora 1; 7, $Q$. r. var. tardiflora 2; 8, Q. r. f. fastigiata; 9, Q. macrocarpa; 10, Q. libani; 11, Q. rubra; 12, Q. petraea 1; 13, Q. petraea 2; 14, Q. petraea 3; M, the number of the base pair.

Markers UBC 841 and UBC 880 showed the highest sampling specificity (Figures 2 and 3 ).

A similar result was obtained previously by LópezAljorna and coauthors in the study of Quercus suber L. [25].

When analyzing the obtained matrix it was determined that the total number of the amplicons did not exceed 12 (UBC 835) and was not less than 2 (UBC 857). The average number of amplified fragments was 7 of five primers. The quantity of monomorphic (unique) fragments ranged from 5 (UBC 857) to 10 (UBC 880). The average percentage of polymorphism for primer UBC 811 was $93.6 \%$; for the UBC $83588.8 \%$; for UBC 841 85.9\%; for UBC $85754.0 \%$; for UBC $88091.6 \%$ (Table 5).

The obtained results allowed constructing the dendrogram of a genetic similarity of the material (Figures 4 and 5).

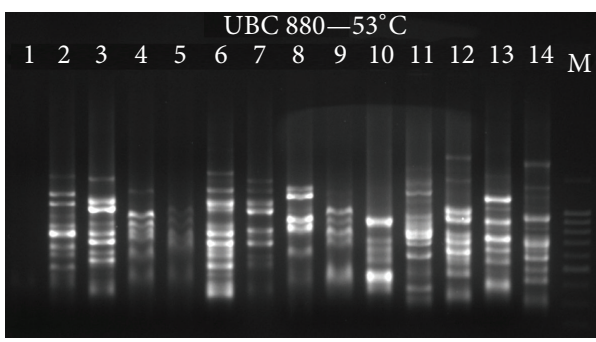

FIGURE 3: PCR detection of oak trees using the primer UBC 880. 1, Q. r. var. praecox 1; 2, Q. r. var. praecox 2; 3, Q. r. var. praecox 3; 4, Q. r. var. praecox 4; 5, Q. r. var. praecox 5; 6, Q. r. var. tardiflora 1; 7, Q. r. var. tardiflora 2; 8, Q. r. f. fastigiata; 9, Q. macrocarpa; 10, Q. libani; 11, Q. rubra; 12, Q. petraea 1; 13, Q. petraea 2; 14, Q. petraea 3; M, the number of the base pair.

The obtained dendrogram was compared to the taxonomic position of the studied species within the genus. Intrageneric taxonomy of these species is shown in Figure 6 $[32,33]$.

Dendrograms obtained by different methods (Figures 4 and 5) were matched with an intrageneric taxonomy of the studied species (Figure 6). In result, the preference was given to the Neighbor-Joining (NJ) method.

It should be noted here that both methods, $\mathrm{NJ}$ and UPGMA, allow clearly identifying clade of «Q. r. var. praecox» and «Q. petraea». Evidently, both these methods will be effective in analyzing the polymorphism in collection of samples from Q. robur and Q. petraea, two closely related species.

The dendrogram of Figure 5 showed three principal groups:

(i) Group 1 with Q. libani Oliv. and Q. rubra L. samples. Both species are most taxonomically distant from $Q$. robur.

(ii) Group 2 «Q. r. var. praecox», which includes all samples of the variety, as well as sample N 2 (Q. $r$. var. tardiflora) that is logical as far as this sample belongs to the same seed generation as that of $Q$. $r$. var. praecox $\mathrm{N} 4$ and $\mathrm{N} 5$ (all samples of these oaks have a common origin).

(iii) Group 3 «Q. petraea», which also includes samples of Q. robur "fastigiata" and Q. macrocarpa that does not contradict to the genera phylogeny.

(iv) Q. r. var. tardiflora $\mathrm{N} 1$ out of clades. 


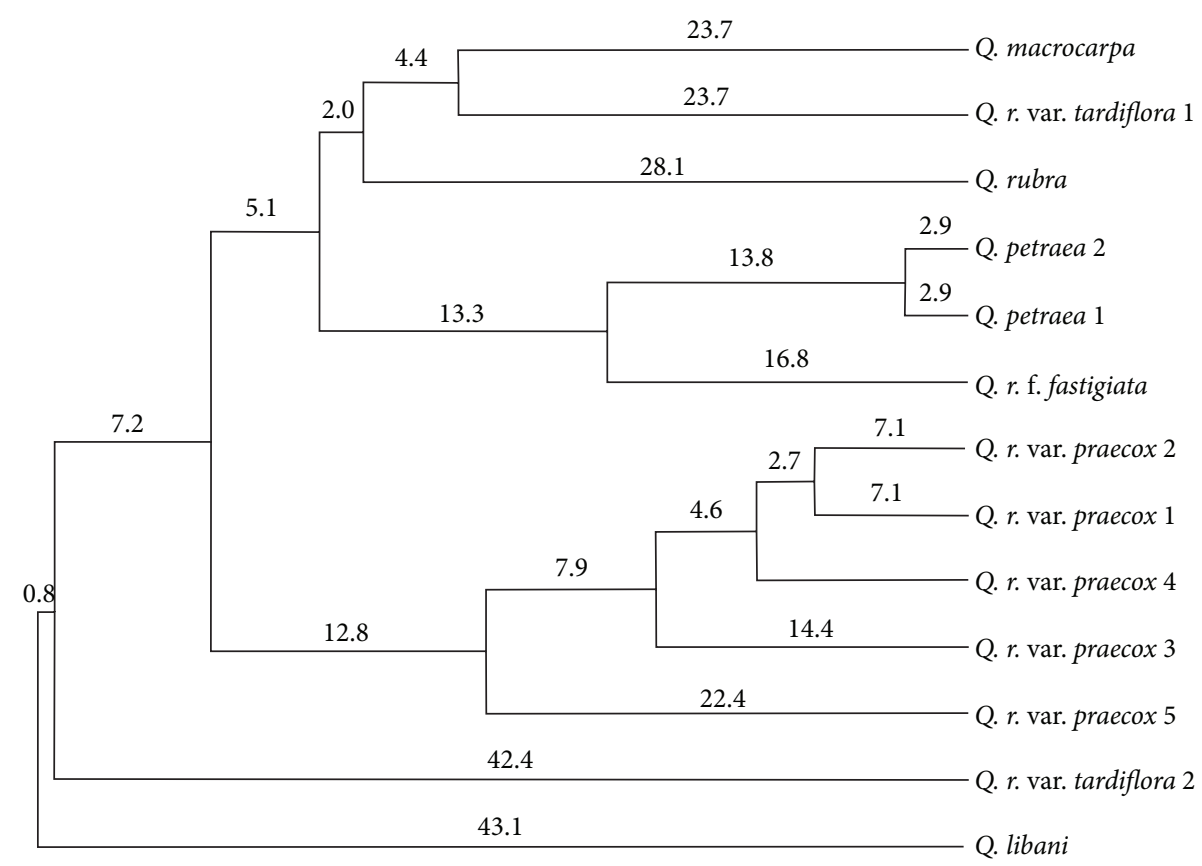

FIGURE 4: Dendrogram representing the genetic affinity of Quercus built by UPGMA on the basis of the electropherogram of primer 841.

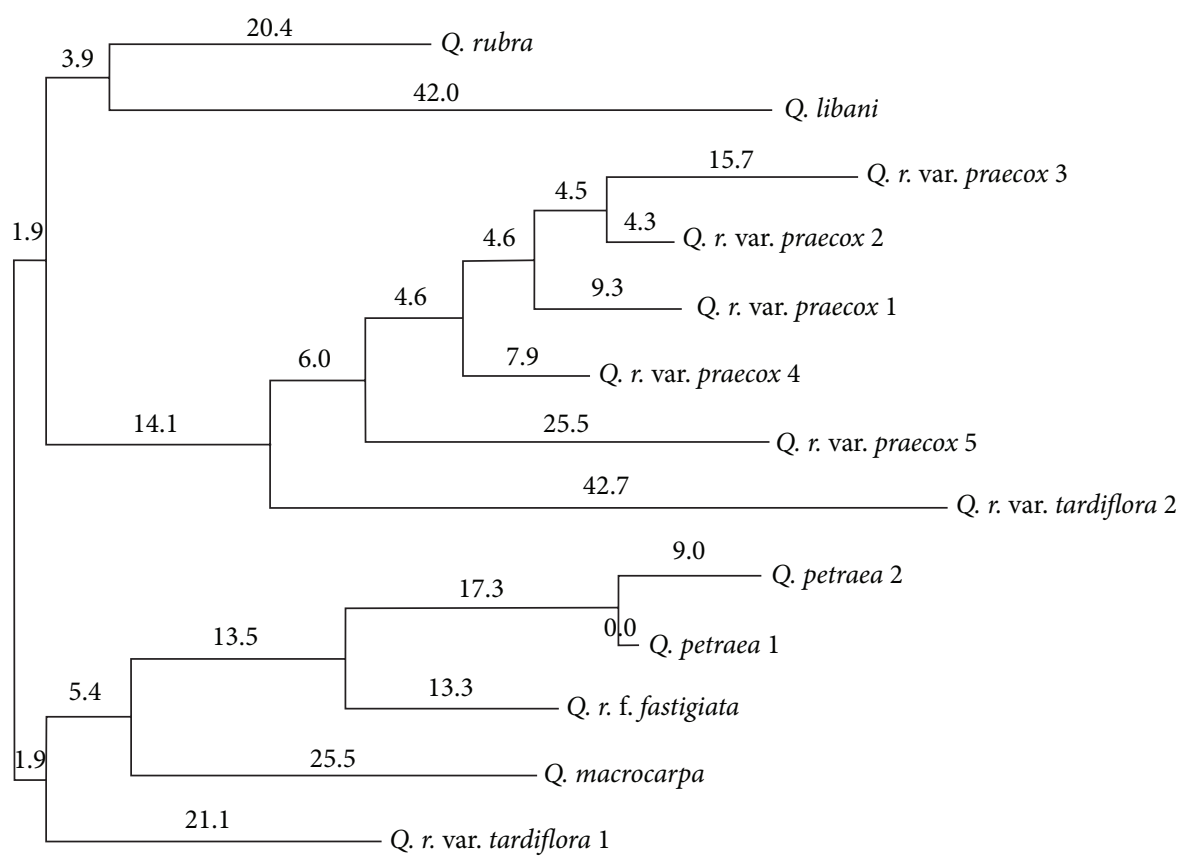

FIGURE 5: Dendrogram representing the genetic affinity of Quercus built by NJ on the basis of the electropherogram of primer 841. 


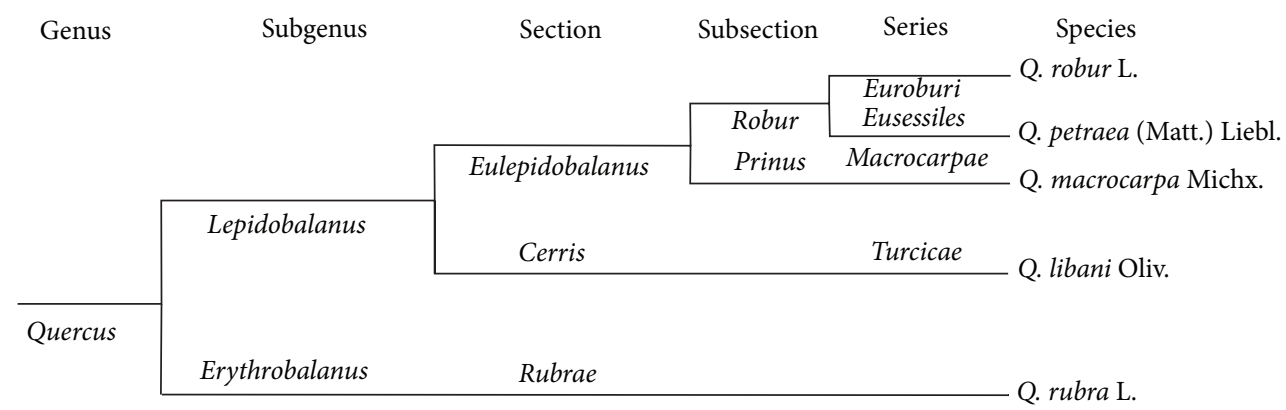

Figure 6: Dendrogram of intrageneric taxonomy of the genus oak (Quercus).

It is significant that in result of dendrogram construction by UPGMA method (Figure 4) this sample appeared to be in a more kinship with North American species, Q. rubra and $Q$. macrocarpa (one clade), than with $Q$. r. var. praecox.

\section{Conclusions}

Analyzing the obtained matrix it was determined that the maximum number of amplicons is 12 (UBC 835) and minimum number of amplicons is 2 (UBC 857). The average percentage of polymorphism for primer UBC 811 was $93.6 \%$; for UBC 835 88.8\%; for UBC 841 85.9\%; for UBC $85754.0 \%$; for UBC 880 91.6\%.

It was showed by analyzing the obtained dendrogram (Figure 5) that Q. libani and Q. rubra samples form Group 1. It is not contrary to the intrageneric taxonomy of the genus oak. Group 2 includes all samples of the variety Q. robur var. praecox and sample of the variety $Q$. robur var. tardiflora $\mathrm{N} 2$. All samples of these oaks have a common origin. The sample $Q$. robur var. tardiflora $\mathrm{N} 2$ belongs to the same seed generation as that of Q. robur var. praecox $\mathrm{N} 4$ and $Q$. robur var. praecox N 5. Group 3 includes all samples of $Q$. petraea and also includes the samples of $Q$. robur "fastigiata" and $Q$. macrocarpa that does not contradict to the genera phylogeny (Figure 6). Sample of Q. robur "fastigiata" belongs to the seed generation of Q. robur var. praecox. Sample Q. $r$. var. tardiflora $\mathrm{N} 1$ is out of clades.

Analysis of polymorphism of intersimple sequence repeats can be used successfully for DNA fingerprinting of varieties of $Q$. robur. The revealed polymorphism of two samples of $Q$. robur. var. tardiflora indicated that similar phenological forms can be based on genetically far-distinct populations, lines, generations, and forms within the $Q$. robur species. Therefore the phenological features of $Q$. robur should not always be considered to be related with its valuable biological and economical characteristics, as it has been done in a number of studies [17-23]. It was shown also that the sample $\mathrm{N} 1$ of Q. $r$. var. tardiflora from the artificial population of the Botanical Garden of SFU has unique characteristics of its phenology, living longevity, and characteristics obtained by ISSR-analysis.

\section{Conflict of Interests}

The authors declare that there is no conflict of interests regarding the publication of this paper.

\section{Acknowledgments}

The project is supported by grant from the Southern Federal University no. 213.01-07-2014/06PChVG and performed with the equipment of Multiaccess Center "Biotechnology, Biomedicine and Environmental Monitoring," Multiaccess Center "High Technology," Laboratory of Plant Physiology and Ecology, and Laboratory of Cellular and Genomic Technologies of Academy of Biology and Biotechnology of Southern Federal University.

\section{References}

[1] T. Wesołowski and P. Rowiński, "Late leaf development in pedunculate oak (Quercus robur): an antiherbivore defence?" Scandinavian Journal of Forest Research, vol. 23, no. 5, pp. 386394, 2008.

[2] A. Kremer, A. G. Abbott, J. E. Carlson et al., "Genomics of Fagaceae," Tree Genetics \& Genomes, vol. 8, no. 3, pp. 583-610, 2012.

[3] A. A. Fedorov, A. L. Takhtadzhyan, A. L. Kursanov et al., "Plant life in six volumes," Moscow Education, vol. 5, p. 496, 1980.

[4] M. N. Kazantsev, "Natural regeneration of pedunculate oak in the forests of green zones Tyumen," in Actual Problems of Forestry Complex of Bryansk, vol. 39, pp. 120-124, Bryansk State Engineering and Technological Academy, 2014.

[5] Y. P. Yefimov, "Impact precipitation gains English oak early and late forms of forest in Central," Genetics, Selection and Introduction of Forest Species, vol. 1, pp. 70-79, 1974.

[6] S. N. Karandina, Growth and Development of Oak in the Valleys of Western Kazakhstan, Science, Moscow, Russia, 1966.

[7] S. S. Piatnitski, Dendrology Course, Kharkov State University, Kharkiv, Ukraine, 1960.

[8] L. P. Bogachenko, Salt tolerance of English oak and elm pinnately branching on the soils of the subzone of light chestnut [Dissertation on Competition of a Scientific Degree of PhD], 1965.

[9] E. S. Migunova, Afforestation on Saline Soils, Moscow Forest Industry, 1978.

[10] P. S. Pogrebnyak, Basics Forest Typology, Ukrainian Academy of Sciences, Kiev, Ukraine, 1955.

[11] G. R. Eytingen, Forest in the Wilderness, Moscow State Publishing House of Agricultural Literature, 1954.

[12] S. N. Karandina, Features of Growth of English Oak (Quercus robur L.) in the Caspian Lowlands, Moscow Publishing House. USSR, 1963. 
[13] B. L. Kozlovsky, O. I. Fedorinova, and M. V. Kuropyatnik, "New and perspective sample of Quercus robur $\mathrm{L}$. for green building and forestation in the Rostov region," Science Journal KubGAU, vol. 106, no. 2, pp. 580-591, 2015.

[14] O. L. Pokhilko, Ecological principles of formation of the assortment of woody plants in gardening of the city of Rostov-on-don [Ph.D. thesis], Southern Federal University, Rostov-on-Don, Russia, 2009.

[15] V. M. Chernyaev, On Forests of Ukraine, Moscow, Russia, 1858.

[16] B. L. Kozlovsky, T. K. Ogorodnikov, M. V. Kuropyatnik, and O. I. Fedorinova, The Range of Woody Plants for Green Building in the Rostov Region, Publishing House of the Southern Federal University, Rostov-on-Don, Russia, 2009.

[17] M. M. Veresin, "About phenological forms of English oak and use them in afforestation," News of Higher Educational Institutions, Forest Journal, no. 3, pp. 3-15, 1958.

[18] Y. P. Efimov, Phenological form of English oak in a central foreststeppe and forest value [Ph.D. thesis], Author's Abstract on Competition of a Scientific Degree of PhD, 1967.

[19] A. I. Milenin, Ecological features phenological varieties of English oak (Quercus robur L.) under the CCA [Ph.D. thesis], Author's Abstract on Competition of a Scientific Degree of PhD, 1997.

[20] A. G. Molchanov, "The intensity of photosynthesis wound and late blooming of forms of English oak in low moisture," in Structural and Functional Deviations from the Normal Growth and Development of Plants: Materials Long Distance Conference, pp. 204-208, Karelian Research Centre, Petrozavodsk, Russia, 2011.

[21] A. G. Molchanov, "The rate of photosynthesis phenological forms of English oak in a humidification nedostatchnogo," Forest Science, no. 4, pp. 31-38, 2012.

[22] V. V. Rubtsov, N. G. Zhirenko, and I. A. Utkin, "The intensity of the current of sap in different phenological forms of oak forest in the southern," Forest Science, no. 5, pp. 44-55, 2007.

[23] I. I. Silchenko, "Phenological form of English oak (Quercus robur L.) In different types of landscapes of Bryansk region," Herald Bryansk State University, no. 4, pp. 158-161, 2012.

[24] J. P. Coutinho, A. Carvalho, and J. Lima-Brito, "Taxonomic and ecological discrimination of Fagaceae species based on internal transcribed spacer polymerase chain reaction-restriction fragment length polymorphism," AoB PLANTS, vol. 7, Article ID plu079, 2015.

[25] A. López-Aljorna, M. Á. Bueno, I. Aguinagalde, and J. P. Martín, "Fingerprinting and genetic variability in cork oak (Quercus suber L.) elite trees using ISSR and SSR markers," Annals of Forest Science, vol. 64, no. 7, pp. 773-779, 2007.

[26] A. A. Gabitova, Pedunculate Oak (Quercus robur L.) in the southern Urals: ecological and genetic analysis of the population structure [Author's Abstract on Competition of a Scientific Degree of $P h D], 2012$.

[27] J. P. Coutinho, A. Carvalho, and J. Lima-Brito, "Fingerprinting of Fagaceae individuals using inter-microsatellite markers," Journal of Genetics, vol. 93, pp. 132-140, 2014.

[28] A. Dzialuk, I. Chybicki, and J. Burczyk, "PCR multiplexing of nuclear microsatellite loci in Quercus species," Plant Molecular Biology Reporter, vol. 23, no. 2, pp. 121-128, 2005.

[29] J. P. Coutinho, A. Carvalho, and J. Lima-Brito, "Genetic diversity assessment and estimation of phylogenetic relationships among 26 Fagaceae species using ISSRs," Biochemical Systematics and Ecology, vol. 54, pp. 247-256, 2014.
[30] M. Nei and W. H. Li, "Mathematical model for studying genetic variation in terms of restriction endonucleases," Proceedings of the National Academy of Sciences of the United States of America, vol. 76, no. 10, pp. 5269-5273, 1979.

[31] Y. R. Van De Peer and R. De Watcher, "TREECON for windows: a software package for the construction and drawing of evolutionary trees for the Microsoft Windows environment," Computer Applications in the Biosciences, vol. 10, no. 5, pp. 569570, 1994.

[32] A. S. Lozina-Lozinskaya, Trees and Shrubs of the USSR, vol. 2 of Publishing House of the USSR Academy of Sciences, 1951.

[33] A. Rehder, Manual of Cultivated Trees and Shrubs Hardy in North America, The Macmillan Company, New York, NY, USA, 1949. 

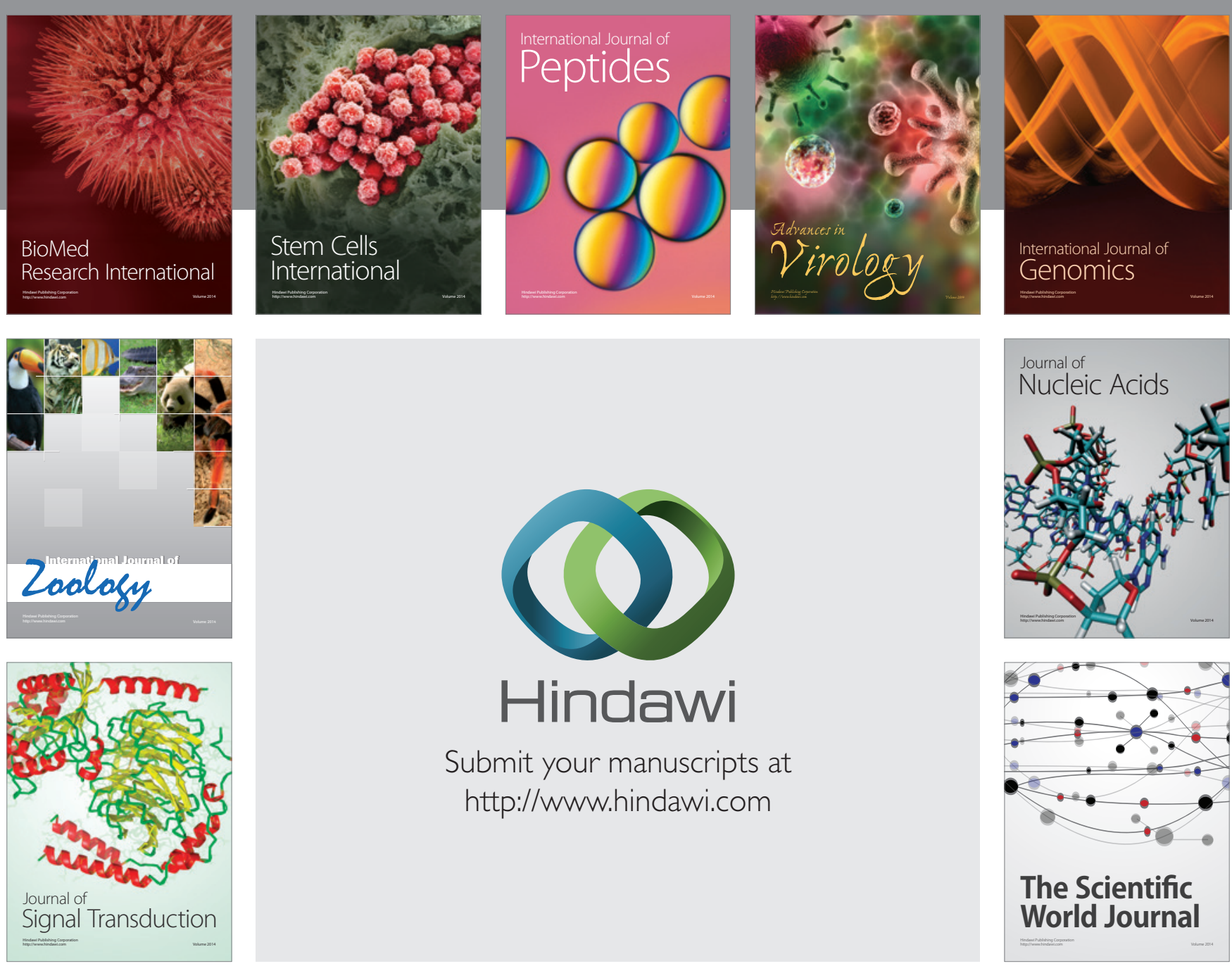

Submit your manuscripts at

http://www.hindawi.com
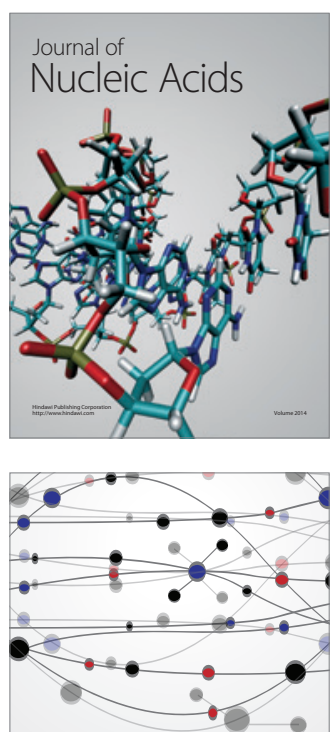

The Scientific World Journal
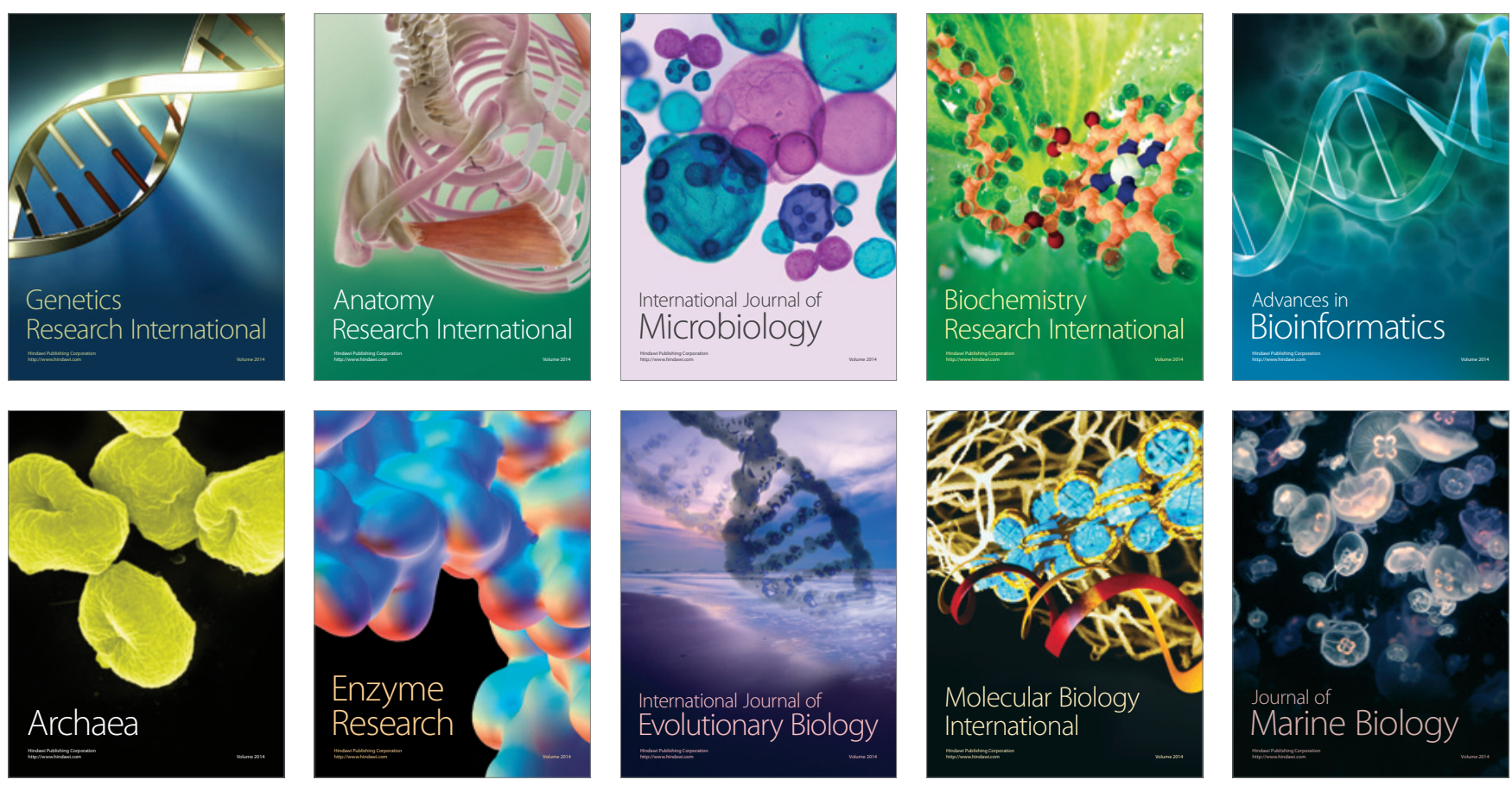